\title{
REKONTRUKSI FIQH ZAKAT PERHIASAN DALAM PERSPEKTIF QADHI ABU SYUJA' AL-ASFAHANI DAN A. HASSAN
}

\author{
Deden Muhammad Jamhur \\ Peneliti INSERT Foundation Bandung Jawa Barat \\ E-Mail: Jamhuro123@gmail.com
}

\begin{abstract}
The issue of zakat would be interesting to be discussed. It is not caused by some kind of zakat, but more. In the fact, Muslim could not be separated from zakat. The zakat is a medium to purify himself and his property. Zakat of Jewelry is one of type of zakat, and became an important position in human life. However, there was a difference of opinion among Muslim scholars about the obligation to implement the zakat of jewelry. Qadhi Abu Syuja' Al-Asfahani said that zakat of jewelry must not to be implemented, but if we has an excess of jewelry. Whereas A. Hassan, he said that zakat should be accomplished without waiting haul and nishab. Zakat of jewelry is something that was not touched directly by the texts of the Qur'an, but the issue of jewelry zakat lies at a certain hadiths. Qadhi Abu Syuja، Al-Asfahani argued based on mawquf hadith from Jabir bin Abdillah. And A. Hassan argued based on the Hadith Shahih. This paper attempts to explain a tought of both scholars about their opinions in implementing of zakat of jawelry.
\end{abstract}

\begin{abstract}
Abstrak
Zakat selalu menarik untuk diperbincangkan, bukan karena banyak jenisnya semata, tetapi lebih dari itu karena pada kenyataannya seorang muslim tidak lepas dari zakat, sebagai media penyucian diri ataupun hartanya. Zakat perhiasan merupakan salah satu jenis zakat yang memiliki posisi penting dalam kehidupan manusia. Karenanya wajar jika muncul perbedaan pendapat tentang kewajiban menunaikan zakat perhiasan. Qadhi Abu Syuja“ Al-Asfahani menghukumi zakat perhiasan tidak wajib ditunaikan kecuali kadarnya berlebihan, sedangkan A. Hassan menghukumi zakat perhiasan wajib ditunaikan tanpa menunggu haul dan nishab. Zakat perhiasan merupakan sesuatu yang tidak tersentuh langsung oleh nash Al-Quran, akan tetapi terdapat pada Hadits-Hadits yang dapat menjelaskan keberadaannya. Qadi Abu Syuja‘ Al-Asfahani tidak mewajibkan zakat perhiasan dengan beristidlal pada Hadits yang mawquf dari Abdillah bin Jabir. Sedangkan A. Hassan berpendapat bahwa zakat perhiasan wajib ditunaikan, dengan beristidlal kepada Hadits yang shahih dan hakim. Makalah ini akan menjelaskan mengenai pemikiran kedua ulama tersebut mengenai pendapat mereka dalam pelaksanaan zakat perhisaan.
\end{abstract}

Kata kunci:

zakat, emas, perak

\section{A. Pendahuluan}

Zakat merupakan salah satu ketentuan agama yang kedudukannya sama dengan shalat, puasa dan haji, sebagaimana tercantum dalam rukun Islam yang lima. ${ }^{1}$ Banyak Hadits-Hadits Rasul yang menjelaskan ten- tang hal itu, diantaranya Hadits yang diriwayatkan oleh Imam Bukhari dan Muslim:

$$
\begin{aligned}
& \text { عن ابي الرحمن عبدالله بن عمربن الظاب رضي الله تعالى } \\
& \text { عنهماقال: سمعت رسول الله صلى الله عليه واله وسلم } \\
& \text { يقول: بني الاسلام على خمس: شهادة ان لا اله الاالله وان }
\end{aligned}
$$

${ }^{1}$ Ayat Dimyati, Hukum Zakat. hlm. 2. 


$$
\begin{aligned}
& \text { محمدا رسول الله واقام الصلاة وايتاء الزكاة وحج البيت } \\
& \text { وصوم رمضان (رواه البخاري ومسلم) }
\end{aligned}
$$

Dari Abu Abdurrahman Abdillah bin Umar bin Khatab r.a, ia berkata: "Aku mendengar Rasulullah SAW. bersabda, Islam itu di bangun di atas lima perkara: bersaksi bahwasannya tidak ada yang haq di ibadahi selain Allah dan bahwasannya Muhammad SAW. adalah utusan Allah, mendirikan shalat, mengeluarkan zakat, haji ke baitullah dan shaum (puasa) pada bulan ramadhan". ${ }^{2}$

Secara umum dan global Al-Quran menyatakan bahwa zakat di ambil dari setiap harta yang dimiliki. ${ }^{3}$ Seperti yang dikemukakan dalam Al-Quran surat Al-Tawbah ayat 103 sebagai berikut:

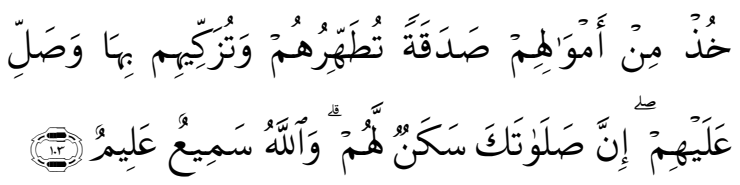

Ambillah zakat dari sebagian harta mereka, dengan zakat itu kamu membersihkan dan mensucikan mereka dan mendoalah untuk mereka. Sesungguhnya doa kamu itu (menjadi) ketenteraman jiwa bagi mereka. Dan Allah Maha Mendengar lagi Maha Mengetahui.

Di zaman Rasulullah SAW. ada empat jenis kekayaan yang dikenakan wajib zakat, keempat jenis itu adalah uang, barang tijarah (dagangan), hasil pertanian seperti gandum, padi dan buah-buahan. Di samping itu, dari jenis ke lima itu yang jarang ditemukan yaitu rikaz (barang temuan atau harta karun yang didapatkan secara kebetulan) karena kelangkaannya. Maka kekayaan yang wajib di keluarkan zakatnya hanya empat jenis saja. ${ }^{4}$

Qadhi Abu Syuja‘ Al-Asfahani dan A. Hassan merupakan dua ulama tersohor yang sangat peduli sekaligus di tantang untuk dapat menyelesaikan masalah-masalah yang dihadapi umat Islam. Qadhi Abu Syuja‘ Al-Asfahani dan A. Hassan melalui pemikirannya sa-

\footnotetext{
${ }^{2}$ An-Nawawi, 2005, hlm. 57.

3Didin Hafidhuddin, Zakat dalam Perekonomian Modern (Jakarta: Gema Insani. 2002), hIm. 15.

${ }^{4}$ Rifyal Ka'bah, Penegakan Syari'at Islam di Indonesia (Surabaya: Khairul Bayan. 2004), hlm. 63.
}

ngat dibutuhkan. Begitu juga dalam berpendapat terhadap masalah-masalah kewajiban dikeluarkannya zakat perhiasan, yang selama ini masih terjadi perbedaan pendapat dan mengganggu pikiran masyarakat.

Keduanya adalah ulama yang memiliki corak pemikiran yang berbeda, dan hidup pada kurun waktu yang berbeda. Apabila dikaitkan dengan mazhab, keduanya bermazhab yang berbeda. Qadhi Abu Syuja‘ Al-Asfahani adalah seorang ulama yang sangat kental dengan pemikiran-pemikiran Imam Syâfi î̀, bahkan beliau merupakan salah satu ulama ternama dari mazhab Syâfi'î. Sedangkan A. Hassan adalah seorang ulama yang corak pemikirannya menyerupai pemikiran Abu Sulayman Ali Al-Asfahani Al-Zhahiri. Walaupun Hassan tidak pernah menyatakan bahwa dirinya adalah pengikut atau pun merupakan salah satu ulama dari mazhab Zhahiri.

Qadhi Abu Syuja، Al-Asfahani menyatakan: "Bahwa emas dan perak yang boleh dipakai menurut hukum agama Islam, seperti cincin atau gelang emas yang dipakai wanita itu tidak wajib dikeluarkan zakatnya, walaupun sudah mencapai nishab." ${ }^{5}$ Hal tersebut berlandaskan kepada Hadits yang diriwayatkan oleh Jabir bin Abdillah dari Rasulullah SAW.:

$$
\text { قال رسول الله صلى الله عليه وسلم: لازكاةف الحلي }
$$

Tidak ada zakat terhadap perhiasan emas dan perak. ${ }^{6}$

Sedangkan A. Hassan berpandangan: "Bahwa zakat perhiasan termasuk di dalamnya emas dan perak wajib dikeluarkan tanpa menghitung nishab dan menunggu haul". A. Hassan berlandaskan kepada Hadits yang diriwayatkan oleh Abu Dawud sebagai berikut:

$$
\begin{aligned}
& \text { قالت ام سلمة: كنت البس اوضاحامن ذهب فقلت: }
\end{aligned}
$$

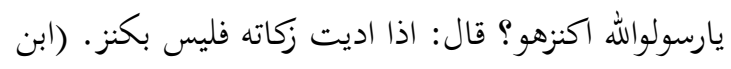

$$
\begin{aligned}
& \text { حجر العسقلاني) }
\end{aligned}
$$

Ummu Salamah telah berkata: "Saya memakai gelang-gelang dari emas, karena itu saya

\footnotetext{
${ }^{5}$ Siradjudin Abbas, Kitab Fiqh Ringkas (Jakarta: Pustaka Tarbiyah. 2004), hlm. 71.

${ }^{6}$ Musthafa Daibul Bigha, At-Tadzhib Al-Haramain (Jeddah: t.pn. 1978), hlm. 95.
} 
berta: Ya Rasulullah, adakah ia termasuk simpanan? (yakni adalah gelang emas saya akan disiksa penyimpanannya?). Rasulullah bersabda: Jika engkau sudah keluarkan zakatnya, maka bukanlah ia barang simpanan lagi". ${ }^{7}$

\section{B. Pembahasan}

\section{Pemikiran Qadhi Abu Syuja‘ Al-Asfahani tentang Zakat Perhiasan}

Abu Syuja، Al-Asfahani adalah seorang ulama yang sangat kental dengan pemikiranpemikiran Imam Syâfi'î, bahkan beliau merupakan salah satu ulama ternama dari mazhab Syâfi'î. Sehingga menggunakan Hadits-Hadits yang diriwayatkan oleh Imam Syâfi'î sebagai landasan hukumnya. Termasuk dalam masalah zakat perhiasan, ada beberapa Hadits yang diriwayatkannya oleh Imam Syâfiî̂ yang menyatakan bahwa emas dan perak yang boleh digunakan sebagai perhiasan oleh wanita tidak wajib dikeluarkan zakatnya.

Sedangkan Imam Syâfi'î adalah seorang ulama besar yang mampu mendalami serta menggabungkan metode ijtihad Imam Malik dan metode ijtihad Imam Abu Hanifah, sehingga menemukan metode ijtihadnya sendiri. Beliau sangat berhati-hati dalam berfatwa, sehingga dalam fatwanya itu ada keseimbangan antara rasio dan rasa. ${ }^{8}$

Qadhi Abu Syuja' Al-Asfahani menyatakan: "Bahwa emas dan perak yang boleh dipakai menurut hukum Agama Islam, seperti cincin atau gelang emas yang dipakai wanita itu tidak wajib dikeluarkan zakatnya, walaupun sudah mencapai nishab". 9

\section{a. Dasar Hukum}

Qadhi Abu Syuja، Al-Asfahani menyatakan: "Bahwa emas dan perak yang boleh dipakai menurut hukum Agama Islam, seperti cincin atau gelang emas yang dipakai wanita

${ }^{7}$ A. Hassan, Kumpulan Risalah A. Hassan (Bangil: Pustaka Elbina. 2005), hlm. 202.

${ }^{8}$ A. Djazuli, Kaidah-kaidah Fikih: Kaidah-kaidah hukum Islam dalam Menyelesaikan Masalah-masalah yang Praktis (Jakarta: Prenada Media Group. 2006), hlm. 116.

${ }^{9}$ Siradjudin Abbas, Kitab Figh. hlm. 71. itu tidak wajib dikeluarkan zakatnya, walaupun sudah mencapai nishab". ${ }^{10}$

Hal tersebut berlandaskan kepada Hadits yang diriwayatkan oleh Jabir bin Abdillah dari Rasulullah SAW.:

$$
\text { قال رسول الله صلى الله عليه وسلم: لازكاةف الحلي }
$$

Tidak ada zakat terhadap perhiasan emas dan perak. ${ }^{11}$

Qadhi Abu Syuja، Al-Asfahani adalah salah satu ulama terkenal dari mazhab Syâfi'î, sehingga menggunakan Hadits-Hadits yang diriwayatkan oleh Imam Syâfiî̀ sebagai landasan hukumnya. Termasuk dalam masalah zakat perhiasan, ada beberapa Hadits yang diriwayatkan oleh Imam Syâfi'î yang menyatakan bahwa emas dan perak yang boleh digunakan sebagai perhiasan oleh wanita tidak wajib dikeluarkan zakatnya, yakni sebagai berikut:

$$
\begin{aligned}
& \text { عن عائشة رضي الله عنها انماكانت تلى ابنات اخيها يتا } \\
& \text { مى في حجرها لهن الحلي فلاتخرج منه الزكاة. }
\end{aligned}
$$

Dari 'Aisyah r.a. bahwasannya dia mengunjungi anak saudaranya yang yatim dirumahnya. Sedangkan mereka memiliki perhiasan (dari emas), dan dia ('Aisyah) tidak mengeluarkan zakatnya." ${ }^{12}$

$$
\begin{aligned}
& \text { Juga Hadits berikut, menyatakan: } \\
& \text { عن ابي مليكة ان عائشة رضي الله عنها كانت تحلى بنات باتلهب وكانت لاتخرج زكاته. }
\end{aligned}
$$

Dari Ibnu Abi Mulaikah, bahwasannya 'Aisyah r.a. memberikan perhiasan emas kepada anak perempuan saudaranya, dan dia tidak mengeluarkan zakatnya."13

Banyak Hadits-Hadits Rasul yang menjelaskan tentang hal itu, diantaranya Hadits yang diriwayatkan oleh Imam Bukhari dan Muslim:

\footnotetext{
${ }^{10}$ Ibid. hlm. 71.

${ }^{11}$ Musthafa Daibul Bigha, At-Tadzhib Al-Haramain. hlm. 96.

${ }^{12}$ Alifuddin El-Islamy Sim Song Thian, Hadits-Hadits Riwayat Imam Syâfi'î (Jakarta: Yayasan Sinar Kebajikan. 1995), hlm. 202.

${ }^{13}$ lbid. hlm. 203.
} 


$$
\begin{aligned}
& \text { عن ابي عبدالرحمن عبدالله بن عمربن الظاب رضي الله تعالى }
\end{aligned}
$$

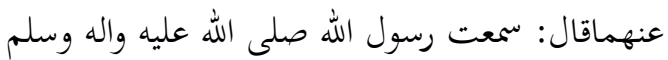

$$
\begin{aligned}
& \text { يقول: بني الاسلام على خمس: شهادة ان لا اله الاالله وان }
\end{aligned}
$$

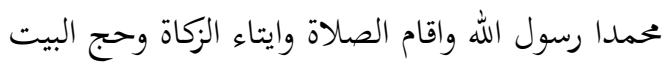

$$
\begin{aligned}
& \text { وصوم رمضان (رواه البخاري ومسلم) }
\end{aligned}
$$

Dari Abu Abdurrahman Abdillah bin Umar bin Khatab r.a, ia berkata: "Aku mendengar Rasulullah SAW. bersabda, Islam itu di bangun di atas lima perkara: bersaksi bahwasannya tidak-lah yang haq di ibadahi selain Allah dan bahwasannya Muhammad SAW. adalah utusan Allah, mendirikan shalat, mengeluarkan zakat, haji ke baitullah dan shaum (puasa) pada bulan ramadhan". ${ }^{14}$

\section{b. Metode Istinbath Al-Ahkam}

Abu Syuja' Al-Asfahani adalah salah satu ulama ternama dari mazhab Syâfi'î, maka fiqihnya-pun tidak berbeda dengan ketentuan yang telah ditetapkan oleh Imam mazhabnya tersebut, termasuk dalam masalah zakat perhiasan. Oleh karena itu Abu Syuja، Al-Asfahani sangat memegang erat pertalian mazhab dalam menetapkan segala masalah, tidak akan berbeda dengan apa yang telah dilakukan oleh Imam mazhabnya yakni Imam Syâfi'î, baik dari segi dasar hukum maupun dari cara atau metode istinbath al-ahkamnya.

Metode istinbath al-ahkam yang digunakan Imam Syâfiî̀ adalah seperti yang dikutip dari buku "Sejarah dan Keagungan Mazhab Syâfi'î". Bahwa Imam Syâfi'î berkata tentang sumber hukum Islam yang dia gunakan untuk mengistinbath al-ahkamnya sebagai berikut: "Yang menjadi pokok adalah Al-Quran dan Sunnah. Kalau tidak ada Al-Quran dan Sunnah barulah qiyas kepada keduanya. Kalau sebuah Hadits dari Rasulullah SAW. sudah shahih sanadnya maka itulah sunnah. ljma lebih besar dari Hadits ahad (kabar orang seorang). Hadits-Hadits itu diartikan menurut dzahirnya lafadz, tetapi kalau artinya banyak maka yang dekat kepada dzahir itulah yang pantas. Kalau bersamaan banyak Hadits maka yang paling shahih sanadnya, itulah yang didahulukan.

\footnotetext{
${ }^{14} \mathrm{Al}$-Thahthawi, 2005, hlm. 57.
}

Hadits munqathi' (yang tidak sampai sanadnya kepada Rasulullah) tidak diterima, kecuali munqathi' yang dikatakan oleh sahabat Sa'id Ibnu Al-Musaya. "Asal" tidak diqiyaskan kepada "Asal". Asal tidak ditanya "Kenapa" dan "Bagaimana". Hal ini hanya boleh ditanyakan kepada furu', "Kenapa"? kalau sudah ada qiyas furu' kepada asal maka itu adalah suatu dalil (hujjah)". ${ }^{15}$

Imam Syâfiî̀ pun pernah berkata dalam Al-Risalahnya, bahwa: "Tidak boleh seorang juga mengatakan dalam hukum sesuatu ini halal dan ini haram, kecuali kalau ada pengetahuannya tentang itu. Pengetahuan itu ialah dari Kitab Suci, Sunnah Rasul, ljma' dan Qiyas". ${ }^{16}$

\section{Pemikiran A. Hassan tentang Zakat Per- hiasan}

A.Hassan berpendapat bahwa semua perhiasan wajib dikeluarkan zakatnya baik yang dijadikan perhiasan maupun yang dijadikan investasi atau yang disimpan, walaupun berbeda dalam waktu mengeluarkannya. Emas dan perak yang dijadikan perhiasan itu dikeluarkan zakatnya saat si pemiliknya membeli perhiasan tersebut tanpa harus menunggu nishab dan haul, tapi hanya sekali selama perhiasan tersebut menjadi miliknya dan tetap sebagai perhiasan bukan sebagai simpanan atau investasi.

Menurut pendapat ulama yang mewajibkan zakat pada perhiasan emas dan perak, karena emas dan perak itu mencakupi perhiasan sebagaimana mencakupi uang dan leburan logam. Maka andai tidak ditunaikan zakat dari padanya dianggap sebagai penyimpanan yang karenanya pemiliknya akan disetrika di hari kiamat.

\section{a. Dasar Hukum}

Syari'at Islam mewajibkan zakat terhadap emas dan perak secara umum, mengingat firman Allah SWT dalam surat AlTaubah ayat 34:

\footnotetext{
${ }^{15}$ Siradjuddin Abbas, Sejarah dan Keagungan Madzhab Syafi'i (Jakarta: Pustaka Tarbiyah. 2006), hlm. 156.

${ }^{16}$ Imam Syafi'i, Al-Umm (Kuala Lumpur: Victocy Agencie. t.th.)
} 


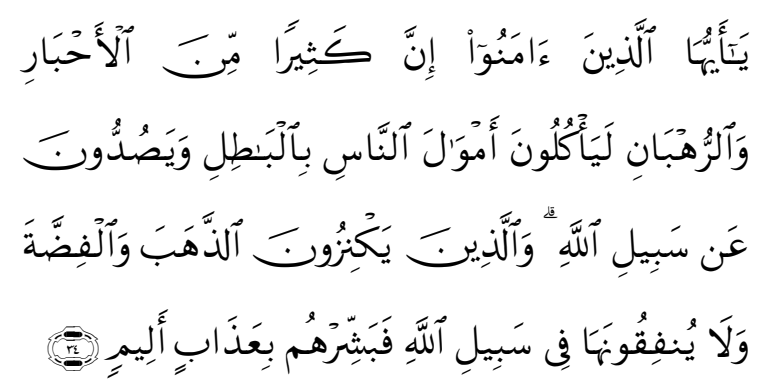

Hai orang-orang yang beriman, Sesungguhnya sebahagian besar dari orang-orang alim Yahudi dan rahib-rahib Nasrani benar-benar memakan harta orang dengan jalan batil dan mereka menghalang-halangi (manusia) dari jalan Allah. dan orang-orang yang menyimpan emas dan perak dan tidak menafkahkannya pada jalan Allah, Maka beritahukanlah kepada mereka, (bahwa mereka akan mendapat) siksa yang pedih.

Dan sabda Rasulullah SAW. yang diriwayatkan oleh Muslim dari Abu Hurairah r.a. bahwa Nabi SAW. bersabda:

$$
\text { من صاحب ذهب ولافضة لايؤدي منها حقها الااذاكان القهان }
$$

Tiadalah bagi pemilik emas dan perak yang tidak menunaikan haknya untuk menzakatkan keduanya, melainkan di hari kiamat ia didudukan di atas pedang batu yang lebar dalam neraka, maka di bakar dalam jahanam, di setrika dengannya pipi, kening dan punggungnya. Setiap api itu padam, maka dipersiapkan lagi baginya (hal serupa) untuk jangka waktu 50 ribu tahun, sehingga selesai pengadilan umat manusia semuanya, apakah ke surga ataukah ke neraka. ${ }^{17}$

Menurut pandangan ulama, yang mewajibkan zakat pada perhiasan emas dan perak beralasan karena emas dan perak dalam aya diatas itu mencakupi perhiasan sebagaimana mencakupi uang dan leburan logam. Maka andai tidak ditunaikan zakat daripadanya di-

\footnotetext{
${ }^{17}$ Yusuf Qardawi, Hukum Zakat (Bandung: Litera Antar Nusa. 2006), hlm. 245.
}

anggap sebagai penyimpanan yang karenanya pemiliknya disetrika di hari kiamat. ${ }^{18}$

Kemudain bersandar kepada apa yang disarankan oleh Hadits tentang zakat perhiasan secara khusus, yang dalam hal ini sekelompok ulama membenarkannya, diantaranya: Apa yang diriwayatkan oleh Abu Daud dari Umar bin Syu'aib dari bapaknya, dari kakeknya bahwa seorang perempuan mendatangi Rasulullah SAW. bersama anak perempuannya dan di tangan anak perempuannya itu terdapat dua buah gelang emas yang berat. Maka Rasulullah SAW. berkata kepadanya: "Apakah ditunaikan zakatnya ini?" Perempuan itu berkata: "Tidak." Nabi bersabda: "Apakah kamu gembira jika Allah SWT menggelangi kamu di hari kiamat dengan dua gelangan neraka?" ia berkata: "Maka saya melepaskan dan memberikannya kepada $\mathrm{Nabi}$, dan kemudian perempuan itu pun berkata: "Keduanya adalah bagi Allah SWT dan Rasul-Nya."

Sesuai dengan Hadits yang dikutip oleh A. Hassan sebagai berikut:

$$
\begin{aligned}
& \text { ان امراة اتت النبي صلى الله عليه وسلم ومعها ابنة لها وين } \\
& \text { يدابنتها مسكتان من ذهب فقا لها: اتعطين زكاة هذه؟ } \\
& \text { قالت: لا. قال ايسرك ان يسورك الله بهما يوم القيامة } \\
& \text { سوارين من نار؟ فالقتهما. }
\end{aligned}
$$

Bahwa seorang perempuan telah datang kehadapan Nabi SAW., dan beserta seorang anaknya perempuan yang memakai dua gelang tangan dari emas. Maka Nabi SAW. Bersabda kepadanya: "Adakah engkau berikan zakatnya ini?” Sahutnya: “Tidak”. Nabi SAW. bersabda: "Adakah menyukakan dikau (lantaran dunia ini) Allah SWT akan pakaikan bagimu dua gelang dari api (neraka) pada hari kiamat? "Maka (perempuan itupun) melemparkan keduanya. ${ }^{19}$

Apa yang diriwayatkan ole Abu Daud, Daruquthni, Hakim dan Baihaqi dari 'Aisyah, ia berkata: "Rasulullah masuk dan menghadap saya, maka beliau melihat ditangku cincin dari lempengan emas. Maka beliau berkata: "Apakah ini ya 'Aisyah?” 'Aisyah men-

\footnotetext{
${ }^{18}$ Ibid. hlm. 277.

${ }^{19}$ A. Hassan, Kumpulan Risalah. hlm. 203.
} 
jawab: "Saya menjadikannya perhiasan untukmu ya Rasulullah." Maka beliau bersabda: "Apakah kamu mengeluarkan zakatnya?" "Aisyah jawab: "Tidak, atau Masya Allah." Maka Nabi SAW. bersabda: "la merupakan bagianmu dari neraka."

Seperti yang dikutip A. Hassan sebagai berikut:

$$
\begin{aligned}
& \text { ان عائسة دخلت على رسول الله صلى الله عليه وسلم فراى : } \\
& \text { في يدها فتخات من ورق. فقال: ماهذا ياعائسة؟ فقالت: }
\end{aligned}
$$

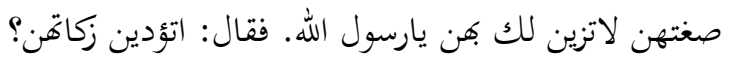

$$
\begin{aligned}
& \text { قالت: لا. قال هن حسبك من النار. }
\end{aligned}
$$

Bahwa 'Aisyah telah datang kehadapan Rasulullah SAW., dengan memakai cincin dari perak, maka Rasulullah SAW. bersabda: "Apakah ini hai 'Aisyah?" Sahutnya: "Saya bikin untuk perhiasan saya untuk (menyenangkan) tuan, ya Rasululullah". Maka Rasulullah SAW. bersabda: "Adakah engkau keluarkan zakatnya?" Sahutnya: "Tidak". Kemudian beliau bersabda: "Cincin-cincin itu cukup untuk memasukanmu ke neraka". ${ }^{20}$

Kemudian apa yang diriwayatkan oleh Abu Daud dan selainnya dari Ummi Salamah, berkata: "Saya memakai kalung emas", maka saya menanyakan kepada Rasulullah SAW.: "Ya Rasulullah, apakah saya menyimpannya?" Rasulullah bersabda: "Apa yang telah sampai (nishab untuk zakatnya)?" Maka zakatkanlah dan jangan disimpan."

Seperti Hadits yang dikutip oleh A. Hassan sebagai berikut:

$$
\text { فقالت أم سلمة: كنت ألبس أوضاحا من ذهب فقلت: }
$$

'Ummu Salamah telah berkata: "Saya memakai gelang-gelang dari emas, karena itu saya bertanya: Ya Rasulullah apakah ia termasuk simpanan? (yakni adakah gelang emas saya termasuk barang simpanan yang akan disiksa penyimpanannya?) Rasulullah bersabda: Jika engkau sudah keluarkan zakatnya, maka bukanlah ia barang simpanan lagi". ${ }^{21}$
Hadits tersebut dinyatakan shahih, memenuhi syarat. Al-Bukhari dan Muslim, dan Al-Dzahabi yang mengoreksi Hadits tersebut membenarkan keshahihannya, memenuhi syarat Bukhari dan Muslim. ${ }^{22}$

Hadits ini diriwayatkan pula oleh Abu Dawd dengan sanad Attab Basyir dan oleh Al-Dâru Quthni dan Hakim dengan sanad Muhammad bin Muhajir dan Tsabit bin Ajlan. Attab bukan orang yang majhul tetapi ia rijal AlBukhari. Hadits Attab baru dinyatakan lemah bila ia terima dai Khusyaith, Tsabit bin Ajlan oleh Ibnu Ma'an dinyatakan tsiqat dan dapat dipercaya. Berdasarkan para ahli peneliti Hadits, maka Hadits Ummu Salamah tersebut derajatnya shahih, ia menunjukan bahwa perhiasan yang terbuat dari emas atau perak itu wajib dikeluarkan zakatnya. ${ }^{23}$

Maka dari Hadits-Hadits di atas, A. Hassan menyatakan bahwa zakat perhiasan wajib ditunaikan tanpa menunggu nishab dan haul.

\section{b. Metode Istinbath Al-Ahkam}

Hassan tidak pernah membatasi secara tegas jumlah sumber hukum itu, tetapi yang pokokkatanya ialah Al-Quran dan Al-Sunnah atau Hadits. Sedangkan ljma' dan qiyas sesungguhnya tidak berdiri sendiri dan tetap merujuk kepada dua sumber itu. ${ }^{24}$

Menurut pengamatan Hassan, ulamaulama Hadits membagi Hadits menjadi dua bagian, yakni yang boleh di pakai dan yang tidak. Hadits yang boleh di pakai di bagi menjadi dua bagian, yaitu mutawatir dan ahad. Mutawatir adalah Hadits yang di dengar dari Nabi SAW. oleh banyak orang, lalu disampaikan kepada orang banyak. Begitulah seterusnya sampai tercatat di kitab-kitab Hadits. Sedangkan ahad ialah Hadits yang diriwayatkan dari Nabi SAW. oleh orang-orang yang tidak sebanyak Hadits mutawatir. ${ }^{25}$

Menurut Hassan, Hadits yang tidak boleh dipakai dibagi menjadi dua bagian, yaitu yang lemah riwayatnya dan yang palsu riwayatnya. Kedua macam Hadits ini tidak boleh

\footnotetext{
${ }^{22}$ Abdurrahman, 2000, hlm. 74.

${ }^{23} \mathrm{E}$. Saefuddin, 2000, hlm. 75.

${ }^{24}$ A. Hassan, Kumpulan Risalah. hlm. 24.

${ }^{25}$ M. Syafiq, 1994, hlm. 25.
} 
dipakai untuk menetapkan sesuatu hukum halal, haram, sunnat dan makruh. la hanya boleh dipakai untuk membantu keterangan saja, bukan jadi pokok pedoman.

Demikian pandangan-pandangan Hassan tentang pemakaian Hadits. Adapun hadits dha'if yang dipakai untuk fadhailul 'amal, Hassan menyatakan keberatan, karena betapa pun hadits dha'if adalah Hadits yang tidak dapat diakui sebagai datang dari Nabi SAW.

Jadi yang bisa dipakai sebagai sumber hukum Islam, kata Hassan adalah Hadits-Hadits yang shahih riwayatnya, disamping tidak bertentangan dengan ayat Al-Quran atau Hadits yang riwayatnya lebih kuat. Jika ada yang demikian, maka Hadits tersebut hendaklah ditakwilkan dengan arti yang tidak menyimpang dari ketentuan bahasa Arab. Tetapi bila tidak mungkin ditakwilkan, maka harus didiamkan (tawaqquf) sementara, yakni tidak dipakai.

Kemudian ljma' yang diakui Hassan ialah ljma' sahabat Nabi SAW. Ijma' ini diterima sebagai sumber hukum Islam, karena percaya bahwa mereka tidak akan berani bersepakat menentukan sesuatu hukum kalau tidak ada landasan yang datang dari Nabi SAW. Sekaligus ini berarti bahwa pada hakekatnya ljma' sahabat itu, menurut Hassan tidak berdiri sendiri. Oleh karena itu, ljma، sahabat tidak perlu dijadikan sumber hukum Islam yang pokok seperti Al-Quran dan Hadits.

Dalam masalahh ibadah, Hassan menolak sama sekali adanya qiyas, karena pemakaian qiyas disitu berarti penambahan baru dalam ibadah. Setiap ibadah selain yang telah ditentukan Allah dan Rasul-Nya terbilang bid'ah. Tampaknya pendapat A. Hassan ini sejalan dengan pendapat Rasyid Ridla yang mengatakan: "Sesungguhnya aku melarang qiyas dalam ibadah mahdhah". Demikian juga Imam Syâfi'î menyatakan lâ qiyâsa fî al-ibadah ("tidak ada qiyas dalam ibadah"). ${ }^{26}$

Istinbath al-ahkam dalam masalah zakat perhiasan, A. Hassan menggunakan Istidlal, yakni langsung mengeluarkan hukum dari AlHadits.

\footnotetext{
${ }^{26}$ E. Saefuddin, 2000, hlm. 22.
}

\section{Analisis Banding Zakat Perhiasan me- nurut Qadhi Abu Syuja‘ Al-Asfahani dan \\ A. Hassan}

Pendapat A. Hasan yang mewajibkan ditunaikannya zakat perhiasan emas dan perak ketika membelinya dengan tanpa menunggu haul dan nishab, sedangkan pendapat Qadhi Abu Syuja، Al-Asfahani yang tidak mewajibkan menunaikan zakat perhiasan emas dan perak yang dipakai, kecuali kadarnya berlebihan. Dalil-dalil yang dijadikan dasarhukum oleh kedua ulama tersebut, maka terlihat adanya ta'arud al-adillah (pertentangan antara dua dalil), sehingga muncul khilafiyah diantara keduanya.

Dalil yang dipegang oleh Qadhi Abu Syuja' Al-Asfahani, yaitu Hadits dari Jabir ibn 'Abdillah, yakni sebagai berikut:

$$
\text { قال رسول الله صلى الله عليه وسلم: لازكاةف الحلي }
$$

Tidak ada zakat terhadap perhiasan emas dan perak. ${ }^{27}$

Sedangkan salah satu dalil yang dipegang oleh $\mathrm{A}$. Hassan tentang wajibnya mengeluarkan zakat perhiasan yang dipakai ketika membelinya, tanpa menunggu nishab dan haul, sebagai berikut:

$$
\begin{aligned}
& \text { ان عائسة دخلت على رسول الله صلى الله عليه وسلم فراى } \\
& \text { في يدها فتخات من ورق. فقال: ماهذا ياعائسة؟ فقالت: }
\end{aligned}
$$

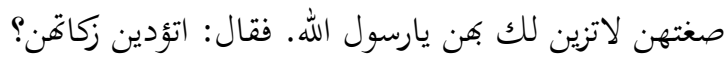

$$
\begin{aligned}
& \text { قالت: لا. قال هن حسبك من النار. }
\end{aligned}
$$

Bahwa 'Aisyah telah datang kehadapan Rasulullah SAW., dengan memakai cincin dari perak, maka Rasulullah SAW. bersabda: "Apakah ini hai "Aisyah?" Sahutnya: "Saya bikin untuk perhiasan saya untuk (menyenangkan) tuan, ya Rasululullah". Maka Rasulullah SAW. bersabda: "Adakah engkau keluarkan zakatnya?" Sahutnya: "Tidak". Kemudian beliau bersabda: "Cincin-cincin itu cukup untuk memasukanmu ke neraka". ${ }^{28}$

\footnotetext{
${ }^{27}$ Musthafa Daibul Bigha, At-Tadzhib Al-Haramain. hlm. 95.

${ }^{28}$ A. Hassan, Kumpulan Risalah. hlm. 203.
} 
Adapun cara penyelesaian dua dalil yang bertentangan (ta'ârud al-adillah), menurut Syâfi'îah, malikiyah, zhahiriyah adalah:

1. Al-Jam'u al-Tauwfiq yaitu mengamalkan kedua dalil lebih baik daripada meninggalkan atau mengabaikan dalil yang lain.

2. Tarjih yaitu menguatkan salah satu;

3. Nasakh yaitu membatalkan salah satu hukum yang dikandung dalam kedua dalil tersebut dengan diketahui dahulu, mana dalil yang pertama dan mana yang datang kemudian;

4. Tatsaqut al-Dalilayn, yaitu meninggalkan kedua dalil tersebut dan berijtihad dengan dalil yang kualitasnya lebih rendah. ${ }^{29}$

\section{Persamaan Pendapat antara Qadhi Abu} Syuja' Al-Asfahani dan A. Hassan

Dalam hal ini penulis dapat menganalisis persamaan atau titik temu dari kedua pendapat diatas, antara lain:

a. Antara Qadhi Abu Syuja' Al-Asfahani dan A. Hassan sama-sama mengistinbath hukum langsung dari Hadits. Walaupun menggunakan Hadits yang berbeda, baik matan rawi dan tingkat keshahihannya;

b. Banyak kesamaan antara Qadhi Abu Syuja' Al-Asfahani dengan A. Hassan dalam menentukan dasar hukum, yaitu:

1) Sama-sama menjadikan Al-Quran sebagai sumber hukum yang utama;

2) Sama-sama menjadikan Hadits sebagai sumber hukum kedua setelah AlQuran;

3) Sama-sama mengutamakan Hadits shahih daripada Hadits ahad dan Hadits dha'if;

4) Sama-sama menerima qiyas sebagai dasar hukum apabila ada kesamaan illat dalam kasus yang berbeda;

5) Sama-sama menerima ljma' walaupun dalam menentukan ljma' tersebut ada perbedaan.

${ }^{29}$ Qadli Abu Syuja‘, Ensiklopedia Hukum Islam (Jakarta: PT Ikhtiat Batu Van Hoeve. 2000), Jilid. V, hlm. 1729.

\section{Perbedaan Pendapat Antara Qadhi Abu Syuja' Al-Asfahani dan A. Hassan}

Antara Qadhi Abu Syuja“ Al-Asfahani dan

A. Hassan dalam masalah zakat perhiasan, terdapat beberapa perbedaan, diantaranya:

a. Antara Qadhi Abu Syuja“ Al-Asfahani dan A. Hassan berbeda dalam menggunakan Hadits, baik dari segi matan, rawi maupun tingkat keshahihannya;

b. Berbeda dalam menentukan ljma'. ljma yang diterima oleh Qadhi Abu Syuja‘ AlAsfahani bukan hanya ljma' sahabat saja, tapi juga ljma' para imam mujtahid, sedangkan A. Hassan hanya menerima ljma' sahabat saja. Karena menurut A. Hassan pada zaman sahabat sangat mungkin terjadi sedikit, dan jarak dari tempat tinggal sahabat yang satu pada sahabat yang lain tidak begitu jauh, sedangkan sekarang tidak mungkin terjadinya ljma' atau kesepakatan semua ulama. Karena ulama pada saat ini sangat banyak dan berjauhan tempat tinggalnya antara ulama yang satu dengan ulama yang lainnya dengan jarak yang sangat jauh;

c. A. Hassan tidak dapat menerima Hadits dha'if walaupun hanya digunakan sebagai dasar fadha'ilul 'amal, jadi bagaimanapun juga, Hadits dha'if tidak diakui bersumber dari Rasulullah SAW., sedangkan dalam mazhab Syâfi'î termasuk di dalamnya Qadhi Abu Syuja‘ AlAsfahani membolehkannya menggunakan Hadits dha'if hanya dalam fadhailul 'amal;

d. A. Hassan hanya menerima qiyas dalam hal duniawi saja, sedangkan dalam masalah ibadah tidak menerima qiyas sama sekali, karena itu dianggap sebagai penambahan ibadah dari ketentuan yang telah ditentukan oleh Allah dan RasulNya;

e. Qadhi Abu Syuja' Al-Asfahani banyak menyandarkan fatwa-fatwanya kepada imam mazhabnya, yakni kepada fatwafatwa imam Syâfi î̀. Sedangkan A. Hassan berdiri sendiri, tidak menyandarkan fatwa-fatwanya yang sama dengan fatwa dari salah satu imam mazhab; 
f. Qadi Abu Syuja' Al-Asfahani tidak mewajibkan zakat pada perhiasan emas dan perak, kecuali kadarnya berlebihan. Sedangkan A. Hassan mewajibkannya ketika membelinya tanpa harus menunggu haul dan nishab.

\section{Penutup}

Penelitian tentang zakat emas dan perak yang dipakai sebagai perhiasan menurut Qadhi Abu Syuja' Al-Asfahani dan A. Hassan dapat diambil kesimpulan sebagai berikut:

1. Qadhi Abu Syuja' Al-Asfahani dengan ijtihadnya berpendapat bahwa perhiasan dari emas dan perak yang boleh dipakai menurut hukum agama Islam, seperti cincin atau gelang emas yang di pakai wanita itu tidak wajib dikeluarkan zakatnya kecuali berlebihan dalam penggunaannya. Sedangkan A. Hassan berpendapat bahwa emas dan perak yang dijadikan perhiasan wajib dikeluarkan zakatnya pada waktu membelinya, dengan tanpa harus menunggu haul dan nishab;

2. Hadits yang dijadikan dasar hukum oleh Qadhi Abu Syuja، Al-Asfahani yang menyatakan bahwa emas dan perak yang dijadikan perhiasan tidak wajib dizakati adalah Hadits yang diriwayatkan oleh Jabir bin Abdillah dari Rasulullah SAW.: "Tidak ada zakat terhadap perhiasan emas dan perak". Sedangkan Hadits yang dijadikan dasar hukum oleh A. Hassan yang menyatakan bahwa emas dan perak yang dijadikan perhiasan wajib dikeluarkan zakatnya adalah Hadits yang diriwayatkan oleh Hakim: "Bahwa 'Aisyah telah datang kehadapan Rasulullah SAW., dengan memakai cincin dari perak". Maka Rasulullah SAW. bersabda: "Apakah ini hai "Aisyah?" Sahutnya: "Saya bikin untuk perhiasan saya untuk (menyenangkan) tuan, ya Rasulullah". Maka bersabda Rasulullah SAW.: "Adakah engkau keluarkan zakatnya?" Sahutnya: "Tidak". Kemudian beliau bersabda: "Cincin-cincin itu cukup untuk memasukanmu ke neraka". Setelah penulis mentakhrij Hadits yang dijadikan dasar hukum oleh Qadhi Abu Syuja‘
Al-Asfahani dan A. Hassan penulis berpendapat bahwa Hadits yang dijadikan dasar oleh Qadhi Abu Syuja“ Al-Asfahani adalah Hadits mawquf yakni periwayatannya hanya sampai kepada sahabat, tidak sampai kepada Rasulullah SAW.. Sedangkan Hadits yang dijadikan dasar oleh A. Hassan adalah Hadits shahih yang sampai kepada Rasulullah SAW., oleh karena itu kedudukan Hadits shahih jelas lebih tinggi daripada Hadits mawquf.

3. Metode Istinbath al-Ahkam yang digunakan oleh Qadhi Abu Syuja' Al-Asfahani ialah dengan beristidlal pada Hadits mawquf. Sedangkan A. Hassan beristidlal pada Hadits shahih.

\section{Daftar Pustaka}

Abbas, Siradjuddin. 2006. Sejarah dan Keagungan Mazhab Syâfi î̀. Jakarta: Pustaka Tarbiyah.

Abbas, Siradjudin. 2004. Kitab Fiqh Ringkas. Jakarta: Pustaka Tarbiyah.

Anonimous, Zakat Perhiasan dan Cara Mengeluarkannya, lihat di http://www.pesantrenvirtual.com/index.php?option=com_ content\&view $=$ article\&id $=736$ :zakatperhiasan\&catid=9:zakat\&Itemid $=61 \quad \mathrm{di}$ akses pada tanggal 19 Juni 2013.

Bigha, Musthafa Daibul. 1978. At-Tadzhib AlHaramain. Jeddah: t.pn.

Djazuli, A. 2006. Kaidah-kaidah Fikih: Kaidahkaidah hukum Islam dalam Menyelesaikan Masalah-masalah yang Praktis. Jakarta: Prenada Media Group.

Hafidhuddin, Didin. 2002. Zakat dalam Perekonomian Modern. Jakarta: Gema Insani.

Hassan, A. 2005. Kumpulan Risalah A. Hassan. Bangil: Pustaka Elbina.

Ka'bah, Rifyal. 2004. Penegakan Syari'at Islam di Indonesia. Surabaya: Khairul Bayan.

Muhammad, Zakat, lihat di http://almanhaj.or.id/content/3684/slash/o/panduanpraktis-menghitung-dan-mengeluarkanzakat-perhiasan/ diakses pada tanggal 07 Mei 2013.

Qardawi, Yusuf. 2006. Hukum Zakat. Bandung: Litera Antar Nusa.

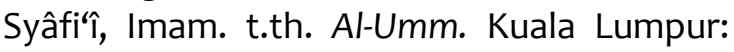
Victocy Agencie. 
144 | Asy-Syari'ah Vol. 16, No. 2, Agustus 2014

Syuja', Qadhi Abu. 2000. Ensiklopedia Hukum Islam. Jakarta: PT Ikhtiat Batu Van Hoeve.
Tim Kajian Baznas, Zakat Emas, Perak,dan Uang, lihat http://pusat.baznas.go.id/zakat-emas-perak-dan-uang/ di akses pada tanggal 23 Juni 2013. 